AIRWAY BIOLOGY

\title{
Reduction of bleomycin induced lung fibrosis by candesartan cilexetil, an angiotensin II type 1 receptor antagonist
}

\author{
M Ołsuka, H Takahashi, M Shiratori, H Chiba, S Abe
}

Thorax 2004;59:31-38. doi: 10.1136/thx.2003.000893

See end of article for authors' affiliations ....................

Correspondence to: Dr H Takahashi, Third Department of Internal Medicine, Sapporo Medical University School of Medicine, South-1 West-16, Chuo-ku, Sapporo 060-8543, Japan;

htaka@sapmed.ac.jp

Received 30 October 2002 Accepted

22 September 2003
Background: Signalling of angiotensin II via angiotensin II type 1 receptor (ATI) promotes cardiac and renal fibrosis, but its role in lung fibrosis is little understood. Using a rat bleomycin (BLM) induced model of pulmonary fibrosis, we examined the expression of ATl in the lung and the effect of an ATI antagonist on pulmonary fibrosis.

Methods: Adult male Sprague-Dawley rats were given $0.3 \mathrm{mg} / \mathrm{kg}$ BLM intratracheally. Two days earlier they had received $10 \mathrm{mg} / \mathrm{kg} /$ day of the ATl antagonist candesartan cilexetil mixed in the drinking water. ATI expression in the lungs was examined by immunohistochemistry and immunoblot methods. The effect of the ATI antagonist on pulmonary fibrosis was studied by analysis of bronchoalveolar lavage (BAL) fluid, histopathology, and hydroxyproline assay.

Results: Immunohistochemical studies showed overexpression of AT1 in inflammatory immune cells, alveolar type II cells, and fibroblasts. A quantitative assay for ATI showed that ATI expression was significantly upregulated in cells from BAL fluid after day 3 and in the lung homogenates after day 21 . Candesartan cilexetil significantly inhibited the increase in total protein and albumin, as well as the increase in total cells and neutrophils in BAL fluid. On day 21 candesartan cilexetil also ameliorated morphological changes and an increased amount of hydroxyproline in lung homogenates. In addition, BLM increased the expression of transforming growth factor (TGF)- $\beta_{1}$ in BAL fluid on day 7 ; this increase was significantly reduced by candesartan cilexetil.

Conclusion: AT1 expression is upregulated in fibrotic lungs. Angiotensin II promotes lung fibrosis via ATI and, presumably, in part via TGF- $\beta_{1}$.
A ngiotensin II, which is mainly generated by angiotensin converting enzyme (ACE) and chymase, is a peptide that plays a crucial role in regulating blood pressure and sodium homeostasis via specific receptors including angiotensin II type 1 receptor (ATl). ${ }^{1}$ Candesartan cilexetil is an ATl selective antagonist and is widely used for the treatment of hypertension. ${ }^{2}$ Recent studies have shown that angiotensin II is also closely associated with tissue injury and fibrogenesis in circulatory organs. The administration of candesartan cilexetil significantly attenuates injury and fibrosis in injured heart models in vivo. ${ }^{34}$ Angiotensin II has been reported to promote the proliferation and collagen synthesis of cardiac fibroblasts inhibited by ATl antagonists. ${ }^{5-7}$ Candesartan cilexetil was found to inhibit peroxide production derived from macrophages. ${ }^{8}$ These results indicate that angiotensin II activates fibroblasts and macrophages by signalling via ATl, resulting in clinical findings of heart injury and fibrosis.

The process of fibrosis is also important in the lung since its progression may result in respiratory failure and a poor prognosis in patients with various types of interstitial lung disorders. The progression of fibrosis is closely related to a complicated network consisting of many cytokines, chemical mediators, growth factors, and biophysical peptides derived from inflammatory immune cells, endothelial cells, and alveolar type II cells. As a member of this network, a pathway via angiotensin II has been reported to be associated with pulmonary fibrosis. A high concentration of ACE has been observed in bronchoalveolar lavage (BAL) fluid from patients with idiopathic pulmonary fibrosis. ${ }^{9}$ In an animal model of radiation induced pulmonary fibrosis, concentrations of ACE and angiotensin II were increased in lung tissue homogenates. ${ }^{10}$ These studies suggest that the process of pulmonary fibrosis is promoted by a local renin-angiotensin system in the lung. Evidence that ATl is localised not only in the heart and kidney but also in the lung ${ }^{11}{ }^{12}$ reinforces this suggestion. Human lung fibroblasts were increased by stimulation of angiotensin II with ATl. ${ }^{13}$ The ACE inhibitor attenuated bleomycin (BLM) induced pulmonary fibrosis. ${ }^{14}$ Administration of an ATl antagonist significantly attenuated radiation induced pulmonary fibrosis. ${ }^{15}$ Taken together, the evidence from these studies suggests that angiotensin II is an important factor in the promotion of pulmonary fibrosis, and ATl is an important receptor for transmission of its signalling. However, the relationship between the expression of ATl and the effect of ATl antagonists in the injured lung in vivo is not clear.

Transforming growth factor (TGF)- $\beta_{1}$ is a key multifunctional cytokine in many fibrotic diseases. Angiotensin II is closely associated with TGF- $\beta_{1}$ production in cardiac and renal fibrosis, ${ }^{16-18}$ which suggests that angiotensin II leads to fibrosis in these models through acceleration of TGF- $\beta_{1}$ synthesis via ATl. TGF- $\beta_{1}$ also acts as a principal fibrogenic mediator in the lung. ${ }^{19-21}$

The aims of this study were (1) to clarify whether the expression of ATl in the lung increases with the progression of fibrosis and, if so, whether candesartan cilexetil attenuates the fibrosis and (2) to determine how it is associated with the cytokine network including TGF- $\beta_{1}$. Using a rat model of pulmonary fibrosis generated by BLM with/without candesartan cilexetil, we examined the relationship between morphological changes, hydroxyproline content, number of inflammatory immune cells in BAL fluid, and the expression of TGF- $\beta_{1}$ and ATl in the lung tissues. 


\section{METHODS}

\section{Animals and preparation of BLM induced pulmonary} fibrosis

Adult male Sprague-Dawley rats weighing 200-220 g (Sankyo Lab, Tokyo, Japan) were anaesthetised and $0.3 \mathrm{mg} / \mathrm{kg}$ BLM (Nippon Kayaku, Tokyo, Japan) in $0.5 \mathrm{ml}$ sterile saline or $0.5 \mathrm{ml}$ of sterile saline (vehicle control) were administered intratracheally. Two days before the administration some rats received $10 \mathrm{mg} / \mathrm{kg} /$ day candesartan cilexetil (Takeda Chemical Industries, Tokyo, Japan) dissolved in the drinking water. Rats were divided into four groups as follows: BLM alone, BLM + candesartan, saline alone, and saline + candesartan. The rats were killed on days $0,1,3,7,14$, or 21 $(n=4-6$ for each group and time point). The lungs were lavaged five times with $7 \mathrm{ml}$ saline and the lavage fluids were centrifuged at $250 \mathrm{~g}$ for 10 minutes to separate the cells and the supernatants. A total cell count was performed with a haemocytometer and differential cell counts were performed on cytospin preparations stained with Wright-Giemsa. Two hundred cells were counted for determination of the differential cell count. The supernatants, resuspended pellets, and lavaged lung tissues were stored at $-30^{\circ} \mathrm{C}$.

\section{Histopathology}

Rats from each group were killed on days 0, 3, 7, 14, 21 and $10 \%$ buffered formalin was intratracheally instilled into the lungs. Lung tissue was embedded in paraffin and lung sections were stained with haematoxylin and eosin for examination by light microscopy.

\section{Immunohistochemistry}

Immunohistochemical analysis of ATl using specific antibody was performed by the avidin-biotin complex (ABC) technique. Paraffin embedded lung sections were dewaxed with xylene, hydrated, and heated at $121{ }^{\circ} \mathrm{C}$ for 15 minutes in a steam steriliser in $10 \mathrm{mM}$ citrate buffer for antigen retrieval. Endogenous peroxidase activity was quenched by the addition of $0.3 \%(\mathrm{vol} / \mathrm{vol})$ hydrogen peroxide in methanol for 30 minutes. The slides were first blocked with $1 \%$ goat serum in phosphate buffered serum (PBS) for 30 minutes. Polyclonal rabbit anti-human ATl antibody (Santa Cruz Biotech, Santa Cruz, CA, USA) was used for the immunostaining. For negative controls, non-specific rabbit IgG was used. The antibodies were used at a dilution of 1:200 (AT1) in PBS. The sections were incubated for 60 minutes with the antibody at room temperature in a moist chamber. Biotinylated anti-rabbit goat IgG was incubated with the sections for 30 minutes and with $\mathrm{ABC}$ solution for 30 minutes (Vector, Burlingame, CA, USA). Immunoreactivity was detected by the addition of $0.5 \mathrm{mg} / \mathrm{ml}$ diaminobenzidine and $0.01 \%$ hydrogen peroxide in $50 \mathrm{mM}$ Tris buffer solution. Between each step the sections were washed three times with PBS over a period of 15 minutes. The sections were counterstained with haematoxylin, dehydrated, and mounted.

\section{Western blot and dot blot analysis of AT 1}

Lung homogenates were centrifuged at $600 \mathrm{~g}$ for 20 minutes at $4^{\circ} \mathrm{C}$ and the resultant supernatants were subjected to Western blot analysis, according to the method of Towbin and colleagues $(n=5) .{ }^{22}$ Cell samples from BAL fluid were sonicated for 15 seconds at room temperature and then subjected to dot blot analysis $(n=5)$. For Western blot analysis, an aliquot of $10 \mu \mathrm{g}$ homogenate was placed in sample buffer ( $4 \%$ sodium dodecylsulfate, $125 \mathrm{mM}$ Tris- $\mathrm{HCl}$, $\mathrm{pH} 6.8,1 \% \beta$-mercaptoethanol, 50\% (vol/vol) glycerol, and $0.01 \%(\mathrm{wt} / \mathrm{vol})$ bromophenol blue) and denatured at $100^{\circ} \mathrm{C}$ for 10 minutes. The homogenate samples were electrophoresed and transferred onto a nitrocellulose membrane over- night. For dot blot analysis, $1 \mu \mathrm{g}$ of cells from the BAL fluid was mounted on a nitrocellulose membrane and air dried. Both membranes were blocked by PBS containing $2 \%$ skimmed milk and $0.1 \%$ Tween-20 for 1 hour. The membranes were washed in $0.1 \%$ Tween-20 in PBS twice for 5 minutes each. Incubation with primary antibody (anti-ATl polyclonal antibody diluted 1:1000 by Tween-20-PBS) was performed for 1 hour at room temperature. After washing the membranes were incubated with secondary antibody conjugated with horseradish peroxidase (anti-rabbit IgG 1:1000 dilution) for 1 hour. The membrane was then subjected to a chemiluminescence detection system (Amersham Pharmacia Biotech, Buckinghamshire, UK) and exposed to $x$ ray film. Densitometric analysis was performed using the NIH image program (http://rsb.info.nih.gov/nih-image/).

\section{Hydroxyproline assay}

Frozen lung tissues were homogenised by a polytron tissue homogeniser in saline containing 0.1 M phenylmethylsulfonylfluoride. The homogenised sample $(n=6)$ was hydrolysed in $6 \mathrm{~N} \mathrm{HCl}$ and the hydroxyproline concentration was determined according to the method of Kivirikko et al. ${ }^{23}$

\section{Protein and albumin assay}

The protein concentration in BAL fluid was measured using the bicinchoninic acid (BCA) method (Pierce Chemical, Rockfold, IL, USA) ( $\mathrm{n}=4-6)$. The albumin concentration in BAL fluid was measured using bromcresol green (BCG) solution (Sigma Co, St Louis, MO, USA) ( $\mathrm{n}=4$ or 5 ).

\section{Measurement of TGF- $\beta_{1}$ in BAL fluid}

BAL fluid samples underwent acidification to convert the latent TGF- $\beta_{1}$ to an active form. $1 \mathrm{~N} \mathrm{HCl}$ was used followed by neutralisation with $1 \mathrm{~N} \mathrm{NaOH}$. Total (latent and active form) TGF- $\beta 1$ levels were measured using a quantitative sandwich enzyme immunoassay kit (Promega, Madison, WI, USA). All samples were assayed in duplicate $(n=4-6)$.

\section{Statistical analysis}

The results are expressed as mean (SD) with mean difference and $95 \%$ confidence intervals (CI) between groups and from day 0 . Statistical analysis was carried out by one way or two way analysis of variance (ANOVA) followed, when differences were significant, by appropriate post hoc tests using the Tukey-Krammer tests. $p$ values of $<0.05$ were considered to be statistically significant.

\section{RESULTS}

\section{Histopathology}

After intratracheal administration of BLM, the histopathological changes in the lung were evaluated on days $0,3,7,14$, and 21 . On day 3 infiltration of neutrophils and macrophages into the alveolar walls and spaces was seen, together with thickening of the alveolar interstitium. These changes were most prominent on day 7. On days 14 and 21 the number of inflammatory cells was small while fibroblasts were numerous, and a mild collagenous deposit with interstitial thickening was observed in the alveolar walls (fig lC). Daily oral administration of candesartan cilexetil resulted in moderate amelioration of inflammatory cell infiltration by day 7 , together with a marked reduction in interstitial thickening by BLM on day 21 (fig 1D).

\section{Immunohistochemistry of AT 1}

The expression of ATl in the lungs of the four groups was immunohistochemically analysed on day 21 . In the lungs of rats in the saline alone group specific immunoreactivity was observed in alveolar macrophages, alveolar type II cells, endothelial cells, and bronchial epithelial cells (fig 2A). ATl 

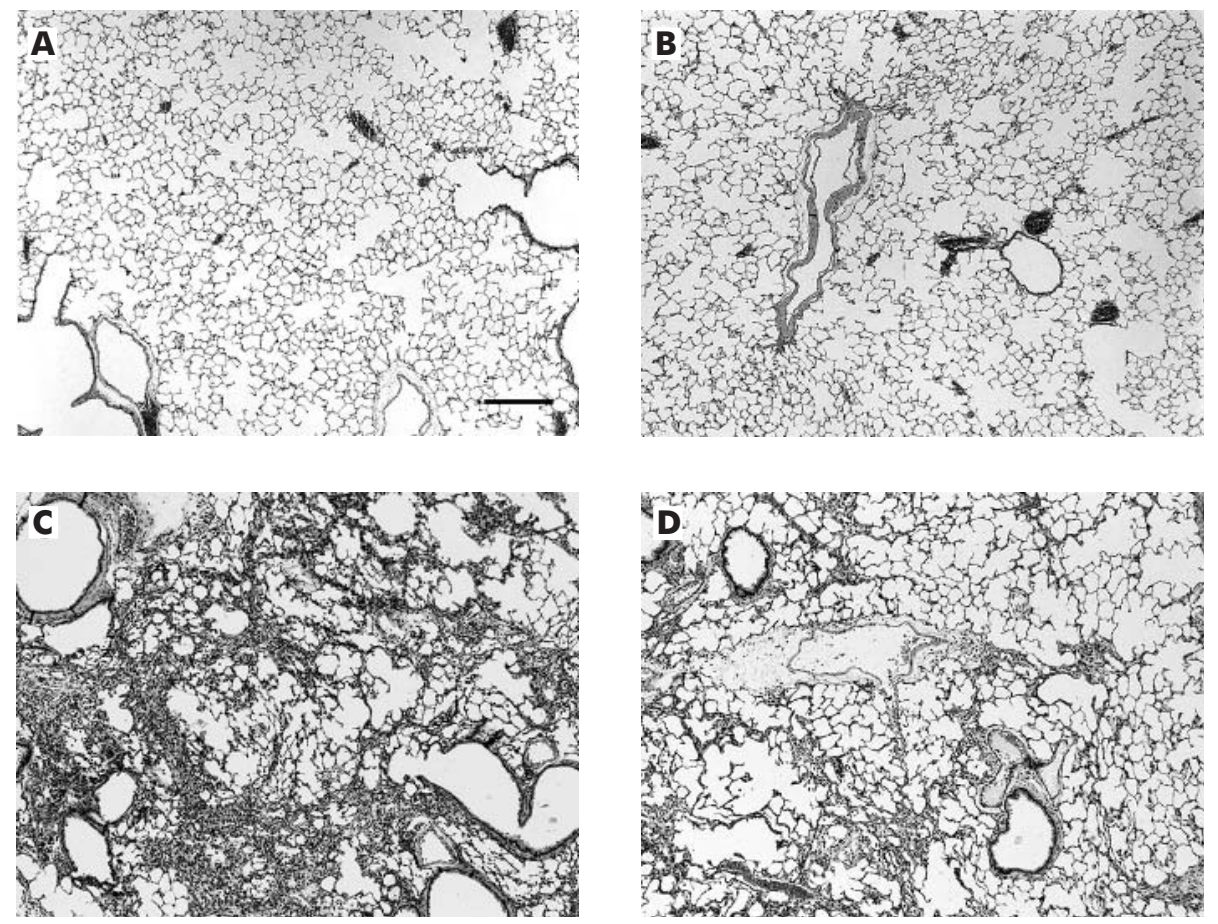

Figure 1 Histopathological findings on day 21 after administration of bleomycin (BLM). The groups given saline alone (A) and saline + candesartan (B) had a normal alveolar structure. The group given BLM alone (C) had marked alveolar thickening and diffuse fibrotic changes with cellular infiltration, while the group given BLM + candesartan (D) had reduced alveolitis and fibrotic changes. Bar $=50 \mu \mathrm{m}$.

positive capillary endothelial cells, interstitial macrophages, and fibroblasts were also observed in fibrotic lesions in lungs from the BLM alone group (fig 2B). The intensity and extent of immunoreactivity did not differ between the BLM alone group and the BLM + candesartan group (data not shown). Negative controls were unstained in all specimens (fig 2C and D).
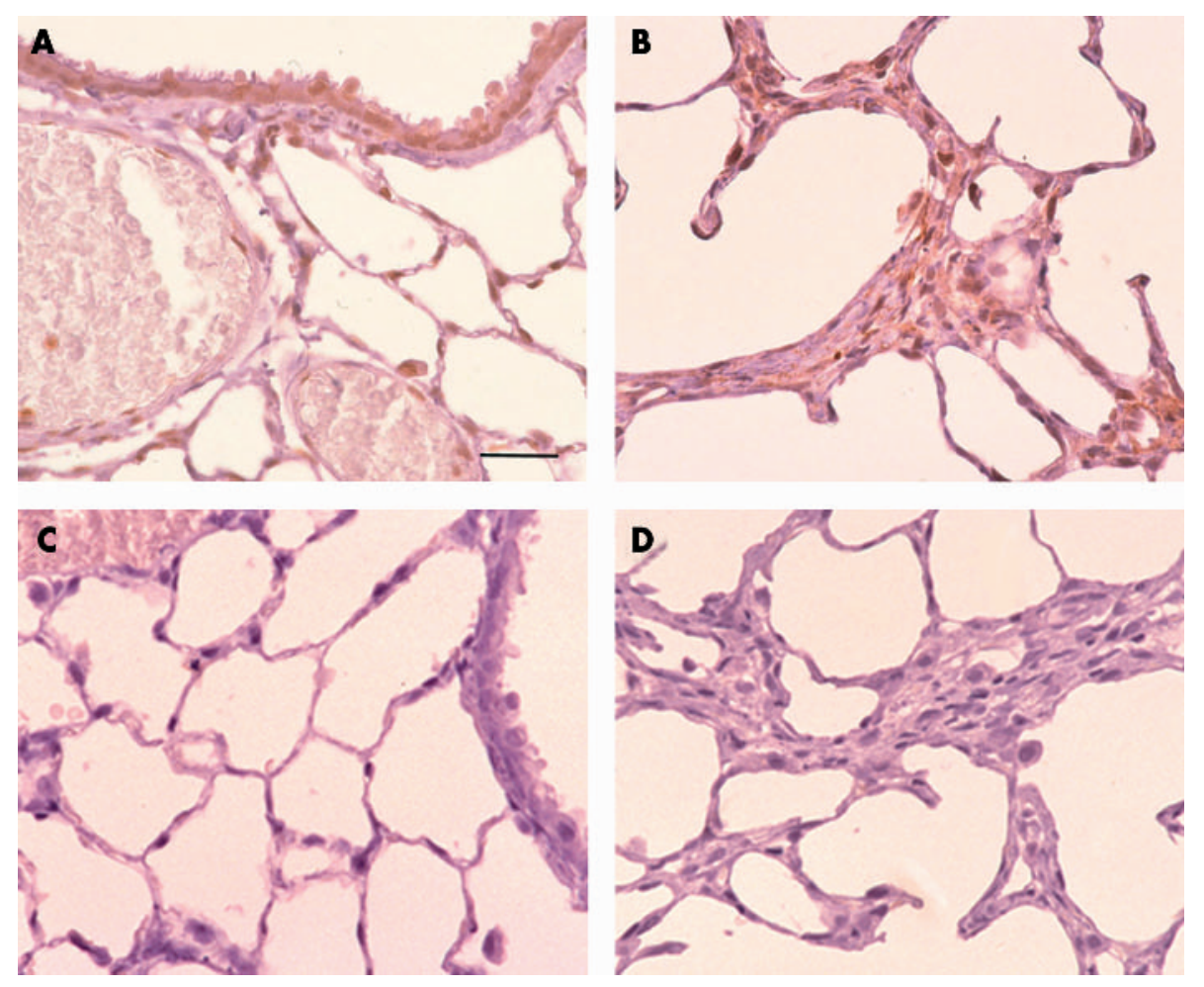

Figure 2 Immunohistochemical study of angiotensin II type 1 receptor (ATI) in (A, C) the saline alone group on day 0 , and (B, D) the BLM alone group on day 21. Immunostaining was performed using (A, B) polyclonal rabbit anti-human AT1 antibody and (C, D) non-specific rabbit lgG. Normal lung section showed specific immunoreactivity in alveolar macrophages, alveolar type II cells, endothelial cells, and bronchial epithelial cells (A). Injured lung sections showed labelling of infiltrated capillary endothelial cells and fibroblasts in the thickened alveolar interstitium (B). The negative controls were unstained in all specimens (C, D). Bar $=25 \mu \mathrm{m}$. 

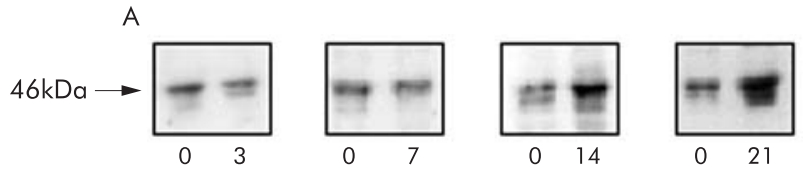

B

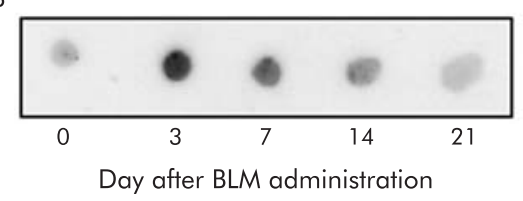

Figure 3 Typical immunoblot profiles of angiotensin II type 1 receptor (AT1) in rats following intratracheal administration of bleomycin (BLM), $\mathrm{n}=5$. (A) Western blot analysis of AT1 expression in lung homogenates at days $0,3,7,14$, and 21 after BLM. Anti-AT1 polyclonal antibody recognised the protein with an apparent molecular mass of $46 \mathrm{kDa}$, which is identical to ATI reported by Harrison-Bernard et al. ${ }^{24}$ The band on the left in each panel shows the control on day 0 . BLM increased the expression of AT1 on days 14 and 21 compared with day $0(n=5)$. (B) Dot blot analysis of ATl expression in BAL fluid cells. BLM administration resulted in an increase in the expression of ATl which was maximal on day $3(n=5)$.

\section{Comparative quantification of AT 1}

The level of ATl expression in the BLM alone group was measured in lung homogenates and BAL fluid cells by Western blot and dot blot analysis, respectively. In lung homogenates on days $0,3,7,14$, and 21 , anti-ATl antibody recognised a protein with an apparent molecular mass of $46 \mathrm{kDa}$ which is identical to that of ATl according to Harrison-Bernard et $a^{24}$ (fig 3A). The time course of ATl expression in both the lung homogenates and BAL fluid cells was significantly different $(p<0.01, p=0.01$, one way ANOVA). ATl expression increased from day 14 (fig 4A), reaching a peak on day $21\left(55.1(10.9) \times 10^{3}\right.$, mean difference $40.0 \times 10^{3}\left(95 \%\right.$ CI $27.3 \times 10^{3}$ to $52.6 \times 10^{3}$, $\mathrm{p}<0.05$ ). A similar increase in ATl expression was observed in BAL fluid cells but the peak level occurred on day 3 (22.0 $(7.13) \times 10^{3}$, mean difference $17.1 \times 10^{3}\left(95 \%\right.$ CI $9.31 \times 10^{3}$ to $\left.24.9 \times 10^{3}, \mathrm{p}<0.05\right)$, much earlier than in lung homogenates (figs $3 \mathrm{~B}$ and $4 \mathrm{~B}$ ).

\section{Hydroxyproline content of lung tissue}

A significant increase in the concentration of hydroxyproline in lung tissue was observed on days 14 and 21 in the BLM alone group but no such increase was seen in the saline alone

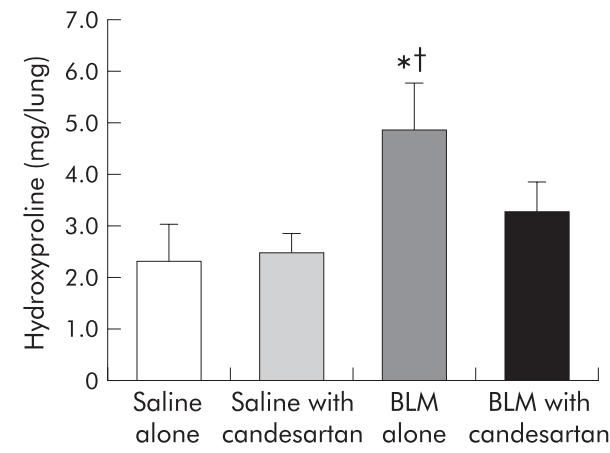

Figure 5 Comparison of hydroxyproline concentration in lung homogenates on day 21 in the four groups $(n=6)$ : saline alone, saline + candesartan cilexetil, bleomycin (BLM) alone, and BLM + candesartan cilexetil. The concentrations were found to be significantly different in the four groups ( $p<0.01$, one way ANOVA). The BLM alone group had a significantly increased hydroxyproline concentration on day 21. Candesartan cilexetil significantly reduced the increase in hydroxyproline content caused by the administration of BLM. Data are shown as mean (SD). ${ }^{*} p<0.05 v$ saline alone group; $\uparrow p<0.05 v B L M+$ candesartan group.

group. The concentrations for all four groups on day 21 are shown in fig 5 . The levels were found to be significantly different in the four groups $(p<0.01$, one way ANOVA). In the BLM alone group the increase in hydroxyproline content (4.83 (0.97) $\mathrm{mg} / \mathrm{lung}$ ) was almost double that in the saline alone group $(2.35(0.71) \mathrm{mg} / \mathrm{lung}$, mean difference $2.49,95 \%$ CI 1.53 to $3.45, \mathrm{p}<0.05)$ and the saline + candesartan group (2.46 (0.41) $\mathrm{mg} / \mathrm{lung}$, mean difference $2.38,95 \%$ CI 1.36 to $3.39, \mathrm{p}<0.05)$. This increase was significantly blocked by candesartan cilexetil (BLM + candesartan group: 3.28 $(0.57) \mathrm{mg} / \mathrm{lung}$, mean difference $1.56,95 \%$ CI 0.59 to 2.53 , $\mathrm{p}<0.05$ ).

\section{BAL fluid cells}

Recovery rates of BAL fluid ranged from $83 \%$ to $100 \%$ and were not significantly different between the four groups. Neither the saline alone group nor the saline + candesartan group showed any significant difference in total cell numbers or differential cell counts during the 21 days. A significant difference in total cell number, neutrophils, and alveolar macrophages was seen between the BLM alone group and the BLM + candesartan group $(\mathrm{p}<0.01, \mathrm{p}<0.01, \mathrm{p}<0.01$, respectively, two-way ANOVA; fig 6). A significant difference was
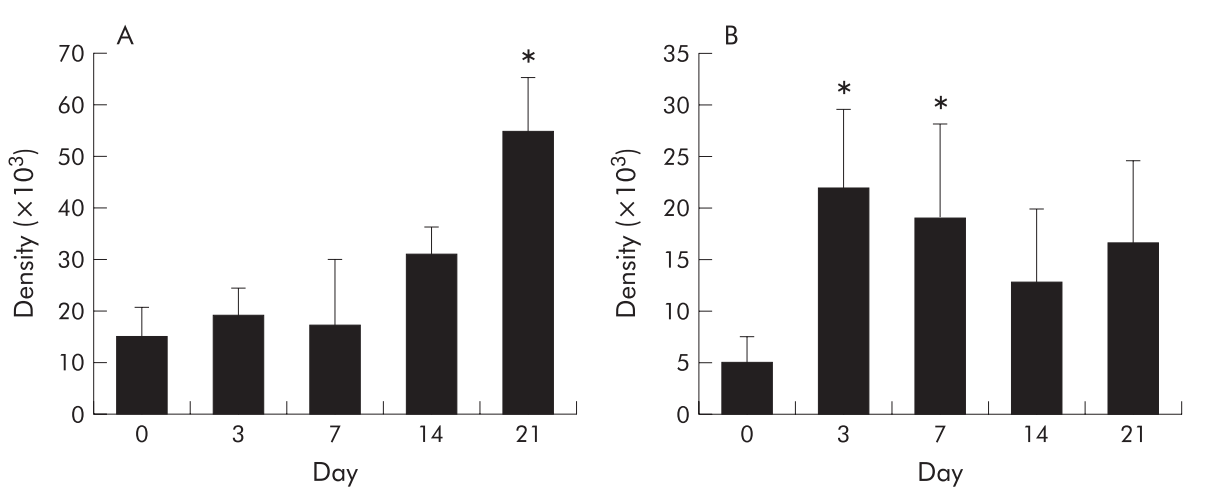

Figure 4 Change in density of angiotensin II type 1 receptor (AT1) expression after administration of bleomycin (BLM) in rats $(n=5)$. The densitometric intensity of each immunoreactive band or spot exposed to $x$ ray film was analysed using the $\mathrm{NIH}$ imaging program. Significant differences between time points were seen in both lung homogenates and BAL fluid cells $(p<0.01, p=0.01$, respectively, one way ANOVA). In lung homogenates (A) the increase in AT1 expression began on day 14 and reached a peak on day 21. In BAL fluid cells (B) AT1 expression had increased rapidly by day 3 and then declined gradually until day 21. Data were corrected to the mean value for day 0 and are shown as mean (SD). ${ }^{*} \mathrm{p}<0.05$ compared with day 0 . 
also seen between time points from day 0 to day 21 . A post hoc test showed that BLM induced a significant increase in mean (SD) total cell counts on days 3, 7, and 14 (day 3: 462 (126) $\times 10^{3} / \mathrm{ml}$, mean difference $359 \times 10^{3}, 95 \%$ CI $224 \times 10^{3}$ to $495 \times 10^{3}, \mathrm{p}<0.05$; day 7: 589 (127) $\times 10^{3} / \mathrm{ml}$, mean difference $486 \times 10^{3}, 95 \%$ CI $350 \times 10^{3}$ to $623 \times 10^{3}, \mathrm{p}<0.05$; day 14: $396(92.9) \times 10^{3} / \mathrm{ml}$, mean difference $294 \times 10^{3}, 95 \%$ CI $191 \times 10^{3}$ to $\left.397 \times 10^{3}, \mathrm{p}<0.05\right)$ compared with baseline levels at day $0\left(102(36.3) \times 10^{3} / \mathrm{ml}\right.$; fig $\left.6 \mathrm{~A}\right)$. The maximal cell number was observed on day 7. Candesartan cilexetil significantly inhibited the increase on day 7 (342 (35.0) $\times$ $10^{3} / \mathrm{ml}$, mean difference $247 \times 10^{3}, 95 \%$ CI $111 \times 10^{3}$ to $383 \times$ $\left.10^{3}, \mathrm{p}<0.05\right)$. The major cellular components of the increase were neutrophils and alveolar macrophages.

BLM induced a significant increase in neutrophils on day 3 which peaked on day 7 (day 3: 263 (71.9) $\times 10^{3} / \mathrm{ml}$, mean difference $262 \times 10^{3}, 95 \%$ CI $188 \times 10^{3}$ to $336 \times 10^{3}, \mathrm{p}<0.05$; day 7: $348(76.6) \times 10^{3} / \mathrm{ml}$, mean difference $348 \times 10^{3}, 95 \%$ CI $269 \times 10^{3}$ to $427 \times 10^{3}, \mathrm{p}<0.05$; fig $6 \mathrm{~B}$ ). The increase on day 7 was the main reason for the increased total cell count and was blocked by candesartan cilexetil (141 (37.7) $\times 10^{3} /$ $\mathrm{ml}$, mean difference $207 \times 10^{3}, 95 \%$ CI $119 \times 10^{3}$ to $295 \times$ $\left.10^{3}, \mathrm{p}<0.05\right)$. Alveolar macrophages were also significantly increased on day $14\left(334(114) \times 10^{3} / \mathrm{ml}\right.$, mean difference 234 $\times 10^{3}, 95 \%$ CI $108 \times 10^{3}$ to $\left.361 \times 10^{3}, \mathrm{p}<0.05\right)$ and this was reduced in the presence of candesartan cilexetil $(193(58.7) \times$ $10^{3} / \mathrm{ml}$, mean difference $141 \times 10^{3}, 95 \% \mathrm{CI}-16.0 \times 10^{3}$ to $298 \times 10^{3}$ ), although the decrease was not significant (fig 6C). There were similar increases in the numbers of lymphocytes and eosinophils but the absolute numbers were extremely small compared with those of neutrophils and alveolar macrophages (data not shown).

\section{Total protein and albumin in BAL fluid}

Neither the saline alone group nor the saline + candesartan group showed any significant changes in the concentration of total protein and albumin during the 21 days. There was a significant difference in the time course of total protein and albumin concentrations in BAL fluid between the BLM alone and the BLM + candesartan groups (both $\mathrm{p}<0.01$, fig 7A and B). A significant increase in total protein was observed on day 3 (509 (64.0) $\mathrm{mg} / \mathrm{ml}$, mean difference $444,95 \%$ CI 391 to 497 , $\mathrm{p}<0.05$ ) and day 7 (501 (191) mg/ml, mean difference 437, $95 \%$ CI 279 to 595, p<0.05) compared with baseline levels on day $0(64.7(64.7) \mathrm{mg} / \mathrm{ml})$. Candesartan cilexetil significantly inhibited the increase in total protein on day 7 (278 (113) $\mathrm{mg} / \mathrm{ml}$, mean difference 224 , 95\% CI 27.8 to 421 , $\mathrm{p}<0.05)$. Similarly, a significant increase in albumin was observed on day 3 (167 (23.7) $\mathrm{mg} / \mathrm{ml}$, mean difference 154 , $95 \%$ CI 138 to $174, \mathrm{p}<0.05)$, on day $7(153(51.2) \mathrm{mg} / \mathrm{ml}$, mean difference $140,95 \%$ CI 97.2 to $182, \mathrm{p}<0.05)$, and on dayl4 (102 (14.9) mg/ml, mean difference 90.0, 95\% CI 75.7 to $102, \mathrm{p}<0.05)$. Candesartan cilexetil inhibited the increase in albumin on days 3, 7 and 14, although this inhibition was not significant. BLM induced a significant difference between time points in the proportion of albumin to total protein $(p<0.01)$, but the difference with candesartan cilexetil treatment was not significant. The proportion of albumin to total protein in the BLM + candesartan group was higher than in the BLM alone group on day 7 (BLM alone: 31.1\%, BLM + candesartan: 44.0\%, mean difference 13.0, 95\% CI 3.78 to 22.2 ; fig 7 C).

\section{TGF- $\beta_{1}$ levels in BAL fluid}

TGF- $\beta_{1}$ levels in BAL fluid supernatants were measured using ELISA kits (fig 8). There was a significant difference between the time course in TGF- $\beta_{1}$ levels in the BLM alone and BLM + candesartan groups $(\mathrm{p}<0.01$ and $\mathrm{p}=0.01$, respectively, two way ANOVA). TGF- $\beta_{1}$ concentrations in the BLM alone group were significantly increased on day 7 (129 (16.3) pg/ml) compared with day $0(27.2$ (12.6) pg/ml, mean difference $102,95 \%$ CI 83.4 to $121, \mathrm{p}<0.05)$. Candesartan cilexetil significantly inhibited the increase on day $7(94.9$ (32.1) $\mathrm{pg} / \mathrm{ml}$, mean difference $34.5,95 \%$ CI 1.78 to 67.2 , p<0.05).
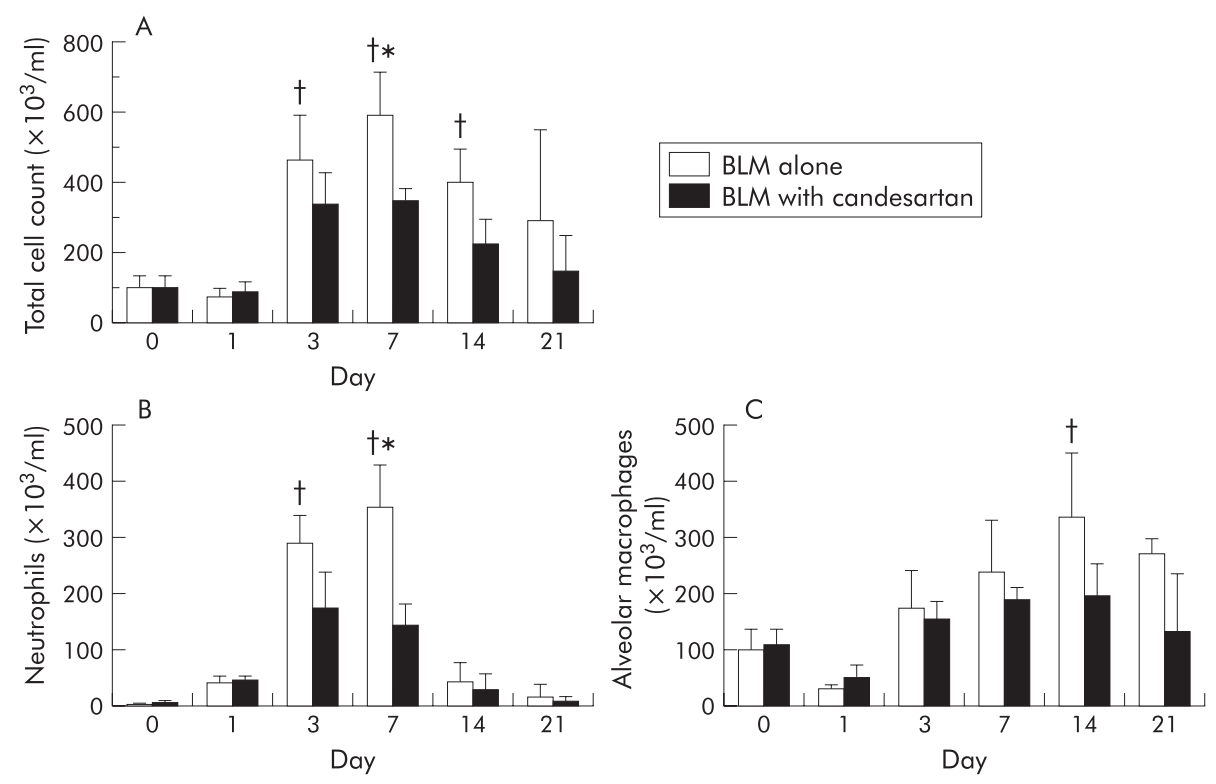

Figure 6 Change in (A) total cell count, (B) neutrophils, and (C) alveolar macrophages in BAL fluid during the 21 days following administration of bleomycin (BLM) and the effect of candesartan cilexetil $(n=4$ or 5). Animals given BLM alone and those treated with BLM + candesartan showed a significant difference in the time course in total cell count, neutrophils, and alveolar macrophages $(p<0.01, p<0.01, p<0.01$, respectively, two way ANOVA). Total cell counts (A) and neutrophils (B) increased significantly and peaked on day 7 . These increases were significantly inhibited by candesartan cilexetil. Alveolar macrophages (C) increased from day 3 and peaked on day 14 ; this increase was reduced with candesartan cilexetil. Data were obtained from five rats and are shown as mean (SD) values. ${ }^{*} p<0.05$ versus $B L M+$ candesartan group; $\uparrow p<0.05$ versus $B L M$ alone on day 0. 

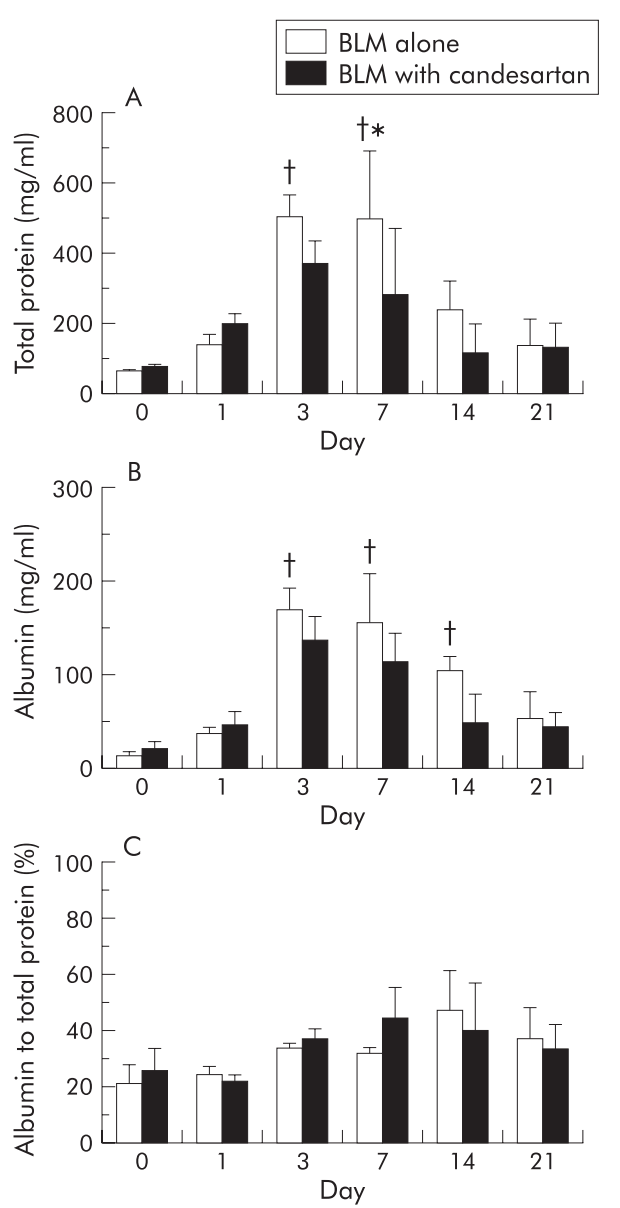

Figure 7 (A) Total protein, (B) albumin, and (C) proportion of albumin to total protein in the centrifuged supernatants of BAL fluid. There was a significant difference in the time course of total protein and albumin concentrations in BAL fluid in the BLM alone and BLM + candesartan groups (both $p<0.01$, two way ANOVA). In the BLM alone group total protein and albumin increased significantly from day 1 . Candesartan cilexetil significantly inhibited the increase in total protein. The proportion of albumin to total protein in the BLM alone group was higher than in the BLM + candesartan group on day 7. Data are shown as mean (SD) values ( $n=4$ or 5$)$. ${ }^{*} p<0.05$ versus BLM + candesartan group; $\mathrm{t} p<0.05$ versus $\mathrm{BLM}$ alone on day 0 .

\section{DISCUSSION}

This study has shown that the expression of ATl is upregulated in BLM induced pulmonary fibrosis and that the ATl antagonist candesartan cilexetil inhibits the synthesis of TGF- $\beta_{1}$ and ameliorates the pulmonary fibrosis. These results suggest that signalling of angiotensin II via ATl promotes BLM induced pulmonary fibrosis.

This is the first report to show the detailed localisation of ATl in the rat lung, although the presence of ATl in human lung has been reported. ${ }^{12}$ ATl in rat lung was localised on alveolar macrophages, alveolar type II cells, vascular smooth muscle cells, endothelial cells, and fibroblasts. These cells are believed to play an important role in the process of fibrosis. The localisation of ATl in normal rat lung, as shown in fig 2, was the same as that in human lung as described in a previous paper. $^{12}$ ATl expression in the lung increased markedly after intratracheal administration of BLM, which is known to generate fibrosis, suggesting that angiotensin II as a ligand of ATl is involved in pulmonary fibrosis. The quantitative assay for ATl showed that the time course of intensity of ATl expression in BAL fluid cells was different from that in lung homogenates. ATl increased as early as day

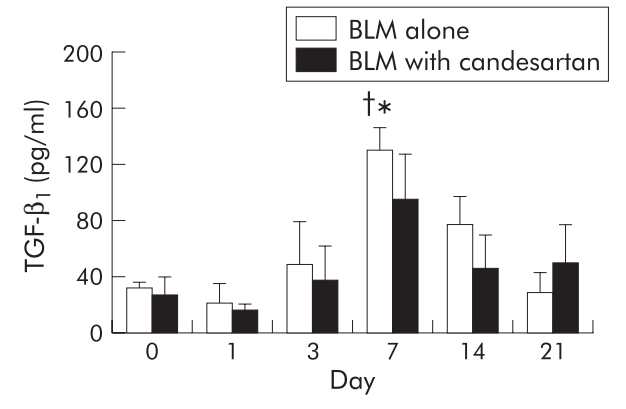

Figure 8 Transforming growth factor (TGF)- $\beta_{1}$ levels in BAL fluid from rats $(n=5)$. There was a significant difference in the time course of TGF$\beta_{1}$ levels in the BLM alone and BLM + candesartan groups $(p<0.01$ and $p=0.01$, respectively, two way ANOVA). TGF- $\beta_{1}$ was significantly increased, reaching a peak on day 7 . This increase was significantly reduced by candesartan cilexetil. Data are shown as mean (SD) values. ${ }^{*} p<0.05$ versus $B L M+$ candesartan group; $\uparrow p<0.05$ versus $B L M$ alone on day 0.

3 in BAL fluid cells, while in the lung homogenates the increase did not take place until days 14-21. This time lag may be due to the different cellular components of these samples. Neutrophils and alveolar macrophages may contribute to the increase in ATl in BAL fluid cells while capillary endothelial cells, interstitial macrophages, and fibroblasts may be the major sources of the increase in the lung homogenates.

Lung fibroblasts are known to proliferate under the stimulation of angiotensin II via ATl.$^{13}$ Since the fibroblast is a major cell component involved in the synthesis of collagen fibres, the increase in ATl in this cell may be critically important for the formation of fibrosis. An increased number of these cells was histopathologically observed on day 21, and the expression of ATl in the lung homogenates continued to increase for 21 days after BLM instillation, suggesting that ATl mediated fibrosis occurs progressively. If chronic types of lung injury such as idiopathic pulmonary fibrosis also maintain a high level of ATl expression, candesartan cilexetil should be administered over a long period in order to achieve a satisfactory therapeutic effect and, moreover, an agent inhibiting the gene expression of ATl should be developed for use as a novel therapeutic strategy.

Activated neutrophils in the alveolar space release toxic radical oxygen species and various proteolytic enzymes which result in severe tissue injury. Many chemotactic factors and adhesion molecules including E-selectin and interleukin (IL)8 are involved in the migration and accumulation of neutrophils in the bronchoalveolar space. The administration of candesartan cilexetil significantly reduced neutrophil accumulation in the bronchoalveolar space, suggesting that angiotensin II may play a crucial role in the acceleration of neutrophil chemotaxis in the BLM injured lung. Previous studies support this suggestion. Angiotensin II generates Eselectin on endothelial cells and promotes leucocyte adhesion to endothelial cells; these effects are inhibited by the ATl antagonist losartan. ${ }^{25}$ The ATl antagonist also inhibits the expression of another adhesion molecule, Mac-1, on neutrophils. ${ }^{26}$ Angiotensin II is itself a potent factor in promoting neutrophil migration ${ }^{27}$; it induces the synthesis of chemotactic factors in endothelial cells ${ }^{28}$ and quinapril, an ACE inhibitor, reduces the synthesis of IL-8 in macrophages in an arteriosclerosis model. ${ }^{29}$ These findings and the results of the present study therefore show that the renin-angiotensin II system is involved in neutrophil accumulation in the BLM injured lung. 
IL-8 is known to be not only a neutrophil chemotactic chemokine but also a pathogenetic mediator of pulmonary fibrosis. ${ }^{30}$ Since neutrophils are a major source of IL- 8 , its predicted overproduction by increased neutrophils in the BLM injured lung is likely to enhance the progression of fibrosis.

TGF- $\beta_{1}$ is the most important factor in mediating pulmonary fibrosis. Patients with idiopathic pulmonary fibrosis and some animal models of pulmonary fibrosis have shown increased TGF- $\beta_{1}$ production. ${ }^{19}{ }^{20}$ TGF- $\beta_{1}$ is mainly produced by alveolar macrophages..$^{21}$ Our study showed that TGF- $\beta_{1}$ levels in BAL fluid increased from day 3 and peaked on day 7 when the increase was significantly inhibited by treatment with an ATl antagonist. These results suggest that angiotensin II promotes pulmonary fibrosis directly or indirectly via the acceleration of TGF- $\beta_{1}$ synthesis. Similar results have been reported in animal models of cardiac and renal fibrosis. ${ }^{17} 18$ In vitro studies have also shown that angiotensin II increases TGF- $\beta_{1}$ synthesis in cultured cardiac fibroblasts, ${ }^{16}$ vascular smooth muscle cells, ${ }^{31}$ bronchial smooth muscle cells, ${ }^{32}$ and renal mesangium cells. ${ }^{33}$ These reports, together with the results of our study, show that angiotensin II plays, in part, a role in accelerating the formation of fibrosis mediated by TGF- $\beta_{1}$ which is partially inhibited by ATl antagonists. Since the major source of TGF$\beta_{1}$ in the BLM induced fibrotic lung seems to be alveolar macrophages, it is necessary to evaluate the expression of ATl by these cells and the subsequent intracellular signal transduction pathway covering the production of TGF- $\beta_{1}$.

Administration of BLM increased vascular permeability of the lung. ${ }^{34}$ Not only BLM itself but also the toxic radical oxygen species and various proteolytic enzymes cause injury to endothelial cells or other structural components of the alveolar-capillary membrane which results in increased vascular permeability. The total protein and albumin content of the BAL fluid are ordinal markers of vascular permeability. ${ }^{34}$ As shown in fig 7, ATl antagonist suppressed the acceleration of vascular permeability caused by BLM. Moreover, analysis of BAL fluid showed that the proportion of albumin to total protein in the BLM + candesartan group on day 7 was significantly higher than in the BLM alone group. This suggests that candesartan cilexetil may reduce the amount of some protein components-probably those related to inflammation-in the bronchoalveolar spaces to a greater extent than it reduces albumin. To evaluate the degree to which major protein components are reduced by candesartan cilexetil it is therefore necessary to identify inflammation related proteins induced by ATl signalling.

In conclusion, our results indicate that ATl expression is upregulated in BLM induced lung fibrosis and ATl antagonist prevents the accumulation of inflammatory cells and development of lung fibrosis. Angiotensin II promotes lung injury and fibrosis via ATl and, presumably, in part via TGF- $\beta_{1}$.

\section{Authors' affiliations \\ M Otsuka, H Takahashi, M Shiratori, H Chiba, S Abe, Third Department of Internal Medicine, Sapporo Medical University School of Medicine, Sapporo Medical University School of Medicine, Sapporo 060-8543, Japan}

\section{REFERENCES}

1 Murphy TJ, Takeuchi K, Alexander RW. Molecular cloning of AT1 angiotensin receptors. Am J Hypertens 1992;5:236-42S.

2 Burnier M, Burnner HR. Angiotensin II receptor antagonists. Lancet 2000;355:637-45.

3 Tanaka A, Matsumori A, Wang W, et al. An angiotensin II receptor antagonist reduces myocardial damage in an animal model of myocarditis. Circulation 1994:90:2051-5.
4 Kojima M, Shiojima I, Yamazaki T, et al. Angiotensin 2 receptor antagonist TCV-116 induced the regression of hypertensive left ventricular hypertrophy in vivo and inhibits the intracellular signaling pathways of stretch-mediated cardiomyocte hypertrophy in vivo. Circulation 1994:89:2204-11.

5 Sadoshima J, Izumo S. Molecular characterization of angiotensin 2-induced hypertrophy of cardiac myocytes and hyperplasia of cardiac fibroblasts. Critical role of AT1 receptor subtype. Circ Res 1993;97:1952-9.

6 Schorb W, Booz GW, Dostal DE, et al. Angiotensin II is mitogenic in neonatal rat cardiac fibroblasts. Circ Res 1993;72:1245-54.

7 Villarreal FJ, Kim NN, Ungab GD, et al. Identification of functional angiotensin II receptors on rat cardiac fibroblasts. Circulation 1993;88:2849-61.

8 Yanagitani Y, Rakugi H, Okamura A, et al. Angiotensin 2 type 1 receptormediated peroxide production in human macrophage. Hypertension 1999;33:335-9.

9 Specks U, Martin WJ 2nd, Rohrbach MS. Bronchoalveolar lavage fluid angiotensin-converting enzyme in interstitial lung diseases. Am Rev Respir Dis 1990;141:117-23.

10 Song L, Wang D, Cui X, et al. Kinetic alterations of angiotensin II and nitric oxide in radiation pulmonary fibrosis. J Environ Pathol Toxicol Oncol 1998;17:141-50.

11 Morrell NW, Grieshaber SS, Danilov SM, et al. Developmental regulation of angiotensin converting enzyme and angiotensin type 1 receptor in the rat pulmonary circulation. Am J Respir Cell Mol Biol 1996;14:526-37.

12 Bullock GR, Steyaert I, Bilbe G, et al. Distribution of type-1 and type-2 angiotensin receptors in the normal human lung and in lungs from patients with chronic obstructive pulmonary disease. Histochem Cell Biol 2001;115:117-24.

13 Marshall R, McAnulty R, Lurent G. Angiotensin II is mitogenic for human lung fibroblasts via activation of the type 1 receptor. Am J Respir Crit Care Med 2000;161:1999-2004.

14 Wang $R$, Ibarra-Sunga $O$, Verlinski L, et al. Abrogation of bleomycin-induced epithelial apoptosis and lung fibrosis by captopril or by a caspase inhibitor. Am J Physiol Lung Cell Mol Physiol 2000;279:L143-51.

15 Molteni A, Moulder JE, Cohen EF, et al. Control of radiation-induced pneumopathy and lung fibrosis by angiotensin-converting enzyme inhibitors and an angiotensin II type 1 receptor blocker. Int J Radiat Biol 2000;76:523-32

16 Lee AA, Dillmann WH, McCulloch AD, et al. Angiotensin 2 stimulates the autocrine production of transforming growth factor-beta 1 in adult rat cardiac fibroblasts. J Mol Cell Cardiol 1995;27:2347-57.

17 Sun Y, Zhang JQ, Zhang J, et al. Angiotensin II, transforming growth factorbeta 1 and repair in the infarcted heart. $J$ Mol Cell Cardiol 1998;30:1559-69.

18 Datta PK, Moulder JE, Fish BL, et al. TGF-beta 1 production in radiation nephropathy: role of angiotensin II. Int J Radiat Biol 1999;75:473-9.

19 Khalil N, O'Connor RN, Unruh HW, et al. Increased production and Immunohistochemical localization of transforming growth factor- $\beta$ in human pulmonary fibrosis. Am J Respir Cell Mol Biol 1991;5:155-62.

20 Khalil N, Bereznary O, Sporn M, et al. Macrophage production of transforming growth factor- $\beta 1$ and fibroblast collagen synthesis in chronic pulmonary inflammation. J Exp Med 1989;170:727-37.

21 Broekelmann TJ, Limper AH, Colby TV, et al. Transforming growth factor beta 1 is present at sites of extracellular matrix gene expression in human pulmonary fibrosis. Proc Natl Acad Sci USA 1991;88:6642-6.

22 Towbin H, Staehelin T, Gordon J. Electrophoretic transfer of proteins from polyacrylamide gels to nitrocellulose sheets: procedure and some applications. Proc Natl Acad Sci USA 1979;76:4350-4.

23 Kivirikko KI, Laitinen O, Prockop DJ. Modification of a specific assay for hydroxyproline in urine. Anal Biochem 1967;19:249-55.

24 Harrison-Bernard LM, El-Dahr SS, O'Leary DF, et al. Regulation of angiotensin II type 1 receptor mRNA and protein in angiotensin II-induced hypertension. Hypertension 1999;33:340-6.

25 Grafe M, Auch-Schwelk W, Zakrzewicz A, et al. Angiotensin II-induced leukocyte adhesion on human coronary endothelial cells is mediated by $\mathrm{E}$ selection. Circ Res 1997;81:804-11.

26 Ito $\mathrm{H}$, Takemori K, Suzuki T. Role of angiotensin II type 1 receptor in the leukocytes and endothelial cells of brain microvessels in the pathogenesis of hypertensive cerebral injury. J Hypertens 2001;19:591-7.

27 Elferink JG, de Koster BM. The stimulation of human neutrophil migration by angiotensin II: its dependence on $\mathrm{Ca}^{2+}$ and the involvement of cyclic GMP Br J Pharmacol 1997;121:643-8.

28 Farber HW, Center DM, Rounds S, et al. Components of the angiotensin system cause release of a neutrophil chemoattractant from cultured bovine and human endothelial cells. Eur Heart J 1990;11(Suppl B):100-7.

29 Hernandez-Presa MA, Bustos C, Ortego M, et al. ACE inhibitor quinapril reduces the arterial expression of NF-kappaB-dependent proinflammatory factors but not of collagen I in a rabbit model of atherosclerosis. Am J Pathol 1998; 153:1825-37.

30 Carre PC, Mortenson RL, King TE Jr, et al. Increased expression of the interleukin-8 gene by alveolar macrophages in idiopathic pulmonary fibrosis. A potential mechanism for the recruitment and activation of neutrophils in lung fibrosis. J Clin Invest $1991 ; 88: 1802-10$.

31 Stouffer GA, Owens GK. Angiotensin II-induced mitogenesis of spontaneously hypertensive rat-derived cultured smooth muscle cells is dependent on autocrine production of transforming growth factor-beta. Circ Res 1992;70:820-8.

32 McKay S, de Jongste JC, Saxena PR, et al. Angiotensin II induces hypertrophy of human airway smooth muscle cells: expression of transcription factors and 
transforming growth factor-betal. Am J Respir Cell Mol Biol 1998; 18:823-33.

33 Kagami S, Border WA, Miller DE, et al. Angiotensin II stimulates extracellular matrix protein synthesis through induction of transforming growth factor-beta expression in rat glomerular mesangial cells. J Clin Invest 1994;93:2431-7.

34 Thrall RS, McCormick JR, Jack RM, et al. Bleomycin-induced pulmonary fibrosis in the rat: inhibition by indomethacin. Am J Pathol 1979;95:117-30.

\section{LUNG ALERT}

New evidence for the Dutch hypothesis?

A Sears MR, Greene JM, Willan AR, et al. A longitudinal, population-based, cohort study of childhood asthma followed to adulthood. N Engl J Med 2003;349:1414-22

his study, designed to evaluate risk factors for the persistence and relapse of asthma, followed children born in Dunedin, New Zealand between April 1972 and March 1973.

A total of 613 subjects (51.4\% of the total study population) underwent spirometry, bronchial provocation, allergy testing, and questionnaires at roughly 2 year intervals between the ages of 9 and 26. Overall, one in four had persistent or relapsing wheeze at the age of 26 . Wheezing was reported at some point by $72.6 \%$ of the population. The risk of persistent/relapsing wheeze was increased by the presence of airway hyperresponsiveness and house dust mite allergy; female subjects were more likely to have persistent wheeze. The chance of relapsing wheeze was greater, the earlier its onset. Compared with the rest of the population, in male subjects with persistent wheeze the fall in the $\mathrm{FEV}_{1} / \mathrm{FVC}$ ratio was, on average, $6.8 \%$ and in female subjects it was $4.7 \%$. However, the slopes of the decline in lung function were similar for all groups, indicating that impairment in lung function existed before the first measurement at the age of 9 .

Given this longitudinal decline in lung function, these findings may be considered to support the "Dutch hypothesis" that falling lung function is due to endogenous factors such as airway hyperresponsiveness leading to airway remodelling and the development of COPD. However, data for $\mathrm{FEV}_{1}$ as a percentage of predicted was not presented, and only $51.4 \%$ of subjects attended all the visits. Clearly, more long term data are needed in this interesting area of study.

\section{Can inactivated Mycobacterium vaccae vaccine help protect HIV positive patients against tuberculosis?}

$\Delta$ Vuola JM, Ristola MA, Cole B, et al. Immunogenicity of an inactivated mycobacterial vaccine for the prevention of HIVassociated tuberculosis: a randomized, controlled trial. AIDS 2003;17:2351-5

nactivated vaccines have better safety profiles than live vaccines in HIV positive subjects, and previous research has shown that immunological responses to non-tuberculous mycobacteria provide protection against tuberculosis (TB).

This study compared the response of both HIV positive $(n=39)$ and HIV negative $(n=10)$ individuals with prior BCG immunisation to five doses of heat inactivated Mycobacterium vaccae (MV) vaccine with a control. Lymphocyte proliferation (LPA) and interferon gamma (IFN- $\gamma)$ responses to MV and Mycobacterium tuberculosis (MTB) antigens were measured at intervals before, during, and after the course. The immune response to MV increased significantly after immunisation and was still evident at $>1$ year. There was a less significant response to MTB antigen in HIV positive subjects. No significant change was seen in the CD4 cell counts or viral loads of HIV positive patients before and after immunisation. There were no major adverse effects.

Inactivated MV vaccine appears to boost BCG primed immunity in HIV positive individuals which may provide protection against the development of active TB. Further large scale trials of the efficacy of this regimen are currently in progress.

V L C White

Locum Consultant Chest Physician, Barts and the London NHS Trust, London, UK; veronica.white@bartsandthelondon.nhs.uk 